\title{
Teaching Civic Engagement through Literature
}

\author{
Ghada Mahmoud Mamdouh Mohamed Abdel Hafeez
}

\begin{abstract}
:
This paper explores different means for advancing a culture of civic engagement through literature and how civic engagement activities pursued by students through the literary texts they study can produce civic capacities that nurture their growth.

Civic engagement through literature can become a pedagogical tool that instructors can use to turn the classrooms into a model of a community devoted to participatory democracy and the students from the apathetic disengaged and self-interested persons to active, motivated and engaged citizens.
\end{abstract}

\section{Rational:}

This paper responds to the growing desire to connect higher education to the civic sphere. Higher education, as the last stage of formal education for most students, should play a pivotal role in shaping the students' characters and developing them as ethical and engaged citizens. Education should turn students from the passive recipients of knowledge to active, responsible participants in the development of their communities. It must go beyond imparting information to the active engagement of analytical and communicative skills that will allow them to participate fully in a fast-changing world.

But because many faculties are often disconnected from the communities of which they are a part and many instructors and students live in ivory towers; hence, my conviction as a professor of English literature, is that we must build civic engagement into the hearts of the undergraduates' learning through literature. The questions here are why literature and how to bridge the gap between literature and civic engagement. The answer simply lies in the fact that literature allows students to see people like themselves represented in the curriculum and allows them too to witness their struggles for freedom, improving society, finding solutions to problems, ... etc. Such perspective helps prepare students for real-world problems and relate the values and ideas expressed in the works of literature to their own lives. Thus, literature can broaden the students' understanding of shared struggles and problems. In addition, it is through literature that, as Judith Langer clarifies, students learn how to explore possibilities and consider options, gain connectedness and seek vision. She adds that they become the type of literate, as well as creative, thinkers that we'll need to learn well at 
college, to do well at work, and to shape discussions and find solutions to tomorrow's problems (2).

Furthermore, through reading and analyzing literary texts, students can be encouraged to address questions of social justice and explore how structures of injustice and inequality are institutionalized and reproduced locally. Studying literature enhances their sense of identity and selfempowerment. It also heightens their awareness and increases their interest in participating in current issues taking place in their local communities, nation and the world in a responsible way. Besides, the critical thinking skills, problem solving, asking questions, engaging in debate, developing empathy that students practice while reading, analyzing and writing about literature are the same types of skills required in other facets of life which allow them to utilize their "voice" as a way to solve their communities' problems.

My contention is grounded in John Dewey's vision of the classroom as a "site of civic engagement in its own right" (qtd. in Spiezio et al. 275) and also in Freire's and Macedo's view of teaching and learning as a "relationship of learners to the world" (viii); hence the literature classroom can become the ideal location to foster the growth of the students into citizens capable of contributing to the common good of their communities through listening, interacting, and solving problems which come naturally both in the literature class and the civic engagement activities.

\section{Objectives:}

This paper seeks to explore how to expand opportunities for teaching civic engagement through literature curriculum and how literature can be used as a tool for the students' active engagement. The paper advocates for the literature classroom to be a site where students learn how to develop the civic capacities and civic efficacy. It also places an emphasis on the necessity of instructors to connect the social issues inherent in the literary texts they are teaching with the current events and incorporate some form of civic engagement in their literature courses. To that end, new pedagogical strategies, which stimulate the students' civic agency, trigger their reflection, and finally empower them to become civically engaged citizens, will be provided.

Although much theoretical work has been written about the importance of civic engagement, there has been less emphasis on how exactly to use literature to create civic engagement among students. The vast body of research does have examples of how civic engagement can be incorporated into individual courses; however, the contribution of this 


\section{Ghada Mahmoud Mamdouh Mohamed Abdel Hafeezr}

paper lies in analyzing three major steps to create civic engagement activities in the literature classroom.

\section{Defining our Terms:}

Civic engagement is defined by Barbara Jacoby as "a heightened sense of responsibility to one's communities" ("Advancing Education" 10), which includes a wide array of activities like participation in community organizations, volunteering, writing letters to editors of newspapers, or any other form of being engaged in solving the communities' problems. In keeping with John Dewey's constant reminder that civic engagement should be informed by education, students have to be fully equipped to participate in their communities' common good. As instructors, we need to cultivate not only civic capacities but also civic efficacy to develop their civic agency that allows them to participate fully in the wellbeing of their communities.

Civic capacities include civic knowledge, civic skills, agency and processes and values (Johnson 45 and Domagal-Goldman 1). Civic knowledge refers to the foundational information that is useful for activities of citizenship; many of which are encountered while reading and analyzing literary texts like justice, equality, essentialism, hegemony, the Other, diaspora, ethnicity, hybridity, and the like. Digesting these entire new and sometimes complicated terms literature students encounter throughout their journey is not an easy task, but the classroom discussions and activities can contribute tremendously to their understanding. It is indispensable to emphasize that having information and understanding the importance of this information are two different things. In preparing our students for their active roles as citizens, they have to integrate knowledge into an understanding of their rights, duties, interests, and affections. As Benjamin Barber declares, "give [students] some significant [civic] power and they will quickly appreciate the need for knowledge but foist knowledge on them without giving them responsibility and they will display only indifference" (234).

Suzanna Morse in her book Renewing Civic Capacity - Preparing College Students for Service and Citizenship (1989) contends the need for the university to enhance the skills and values that lead to the students' abilities to be able to talk, listen and act together with a group of other citizens for the public good (vi). In addition, Kimberley L. Canfield asserts the importance of developing what he calls the "social skills of the citizen," which include the art of conversation, the ability and propensity to be honest, and a sense of multicultural tolerance (217). As Barbara Jacoby clarifies in her article, "Civic Engagement in Today's Higher Education," civic engagement involves one or more of the following: 
Learning from others, self, environment to develop informed perspectives on social issues, valuing diversity and building bridges across difference, behaving, and working through controversy, with civility, participating actively in public life, public problem solving, and community service, developing empathy, ethics, values, and sense of social responsibility. (9)

As for civic attitudes/values, they "combine social concern for others and a moral duty to become involved in community affairs to try to better one's surroundings" (Johnson 45). This means that literature students should not only become aware of the dynamics of race, class and gender for example they encounter while reading and analyzing literary texts, but they should act upon any form of injustices like racism, classicism, antinaturalism, ... etc. which they encounter in their daily interactions.

In addition to civic knowledge, skills and attitudes/values, civic capacities also include processes (e.g. how to register to vote) (DomagalGoldman 3) and civic agency, which can be broadly defined as "the capacity of each individual, working alone or in groups, to view what happens in the world in a critical way and to think about how to bring about positive change (Forestiere 456). Finally, there is civic efficacy which is advanced through repeated experiences of successful performance as well as the anticipation of competent performance (qtd. in Johnson 46). This clearly refers to the students' genuine belief in their capabilities to make a difference in their communities and to address the social problems they encounter in their everyday lives.

To university instructors who wish to incorporate civic engagement activities into their courses but unsure how to begin, I propose the following path that can empower students, embody the ideas they study, and consequently help them act as citizens.

\section{Infusing democratic classroom approach to the literature course management:}

Literature classes cannot only be fertile learning environment but also rich sites for community responsibility and applied knowledge, in which the students' awareness of the social issues can be enhanced as they start examining their own social interests in relation to the literary texts under study. For this to happen, the classroom has to be democratized, which means giving the students the freedom to learn and choose, having the responsibility for self and others, and working together toward a goal and equal opportunity.

This approach to learning is described by Joe Coleman in his article "Civic Pedagogies and Liberal-Democratic Curricula" as "democratic learning" which he defines as a form of pedagogy that reflects the 


\section{Ghada Mahmoud Mamdouh Mohamed Abdel Hafeezr}

introduction of democratic modes of decision making into the classroom (751). This approach encourages students to participate collectively in the governance of the course including rules/protocol of behavior, the construction of the syllabus, the types of assessments, activities and/or projects. It gives them the space to contribute, allows them to discuss and decide whenever possible and gives their input and provides them with opportunities to take responsibilities and to demonstrate what they have learned, which creates horizontal power relationships in the classroom.

Meade and Weaver maintain that building a democratic classroom is aligned with the notion of intrinsic equality, which takes place when instructors engage students in a number of socially-meaningful activities which encourage students to take responsibility for their own learning. This can be achieved in several ways like the selection of the types of assignments required, the selection of a favorite literary text to analyze, present, or speak about. This empowers students and nurtures their abilities and self-worth. As the authors clarify the main purpose of such pedagogical techniques is to "enable the classroom [to] become a model of a community devoted to participatory democracy" (22).

Literature classes like all classes can be democratic or undemocratic. If lecturing is the only mode of instruction, facts and tests are the primary concerns, and students are safe in their comfort zones, then the classroom is an inhospitable terrain for the promotion of engaged citizenship. But if we invite students to participate in discussions and accept the conflicting points of views that come from multifaceted readings, we "legitimize a democracy of voices" (Pradl x) and consequently enable active and assertive ways of expression.

\section{Crafting the citizen-to-be through civic engagement pedagogies:}

Since the goal of this paper is encouraging students to be civically engaged through literature, the question then becomes what are the pedagogies that instructors can utilize in order to achieve this goal. For many instructors, the answer lies in incorporating some forms of civic engagement through adopting "civic instruction" (Palmer and Standerfer 126), which can be defined as pedagogical strategies and instructional techniques that are student-centered, participatory in nature and dedicated to the promotion of students' engagement in the classroom and the local community. Many of the skills necessary for civic engagement are not cultivated through authoritarian teaching methods, but through active and innovative teaching methods that enhance active citizenship inside and outside the classroom. W.J. McKeachie et al. have pointed out that teaching methods that actively involve students in the learning process and provide them with opportunities for interaction with their peers as 
well as with faculty enhance the students' content learning, critical thinking, transfer of learning to new situations, and such aspects of moral and civic development as a sense of social responsibility, tolerance, and nonauthoritarianism (70).

"Civic instructions" encompass a considerably broad range of instructional practices. In addition to what Joe Coleman described as "democratic learning," he adds "cooperative learning" and "constructivist pedagogy" (749) as two more examples of this civic-based instruction. Cooperative learning refers to a variety of teaching methods in which students work in small groups to help one another learn academic content. In cooperative classrooms, students are expected to help each other, to discuss and argue with each other, to assess each other's current knowledge and fill in gaps in each other's understanding (Slavin 2). Constructivist pedagogies share a similar interest in the students' abilities to construct meaning "grounded in their own experience rather than simply absorbing and reproducing knowledge transmitted from subjectmatter fields" (Newman et al. 280-81). Constructivist pedagogies may be conducted through small group discussions; cooperative learning tasks; independent research projects; using arts; using of computer and video technology; using community-based projects such as surveys, oral histories and volunteer service (Newman et al. 281).

This means adopting hands-on activities, which include - but not restricted to - the following: "Democratic conversations" which "begin with students listening to themselves" (Pradl 51) and then explore new possibilities. Gradually, students discover that a single reading stimulates diverse responses, which open up new meanings for them. Consequently, "literature classrooms might be caldrons of democracy" and hence "legitimize a democracy of voices" (Pradl ix, x). Debate is another teaching strategy that develops the students' skills like doing good research, analyzing the topic under discussion, fining alternative approaches, presenting different solutions, tolerance of opposing ideas, civic skills. Role playing is a third teaching strategy that can engage students because as Erich Mistrik has highlighted when students play the roles consciously, they put their own attitudes and emotions unconsciously.

In addition, using the technology of the internet for the purposes of engagement is important. Digital pedagogy, which includes digital portfolios and blogs, are imperative to cope with the digital culture we all experience. J. Elizabeth Clark has referred in her article "The Digital Imperative: Making the Case for a $21^{\text {st }}$ Century Pedagogy," to the fact that digital portfolios or ePortfolios encourage students to make 


\section{Ghada Mahmoud Mamdouh Mohamed Abdel Hafeezr}

connection between their academic and lived lives, which is a major tenant in civic education (29-30). The blog is another digital form that engages students and they can contribute regularly to it; it even allows them to share it with their families and friends.

Furthermore, students are encouraged to keep personal blogs which focus on the social issues related to the class themes or they can contribute to a class blog. They are also encouraged to interview their parents or grandparents to solicit and discuss their views on some public issues related to the literary texts they are analyzing; in this case as Margaret Stimman Branson asserts in her article, "Education for Informed, Effective, and Committed Democratic Citizenship," that "all generations make civic gains." Moreover, to engage students in any of the social issues discussed in the classroom, they can be asked to find articles related to the course and to provide critical commentary on the articles in the course blog.

Utilizing such student-centered cooperative approaches foster toleration and equal respect by exposing students to the diversity that already surrounds them in the guise of their classmates; a virtue which is required for citizenship (Coleman 754). Exposing them to the civic sphere through the literary texts allow the students to inquire, discover and learn with and from one another and understand the civic knowledge in more practical and thorough terms than they would if their educational activities have been confined to the classroom and enhance their comprehension.

\section{Connecting the course content to issues in the local or} national communities:

As literature instructors, we have the responsibility to not only teach our students that social problems are ingrained in the fabric of our society but also to keep them informed of the current events and social issues and finally prepare them to respond to real situations in the present, thereby creating citizenry. By bringing contemporary issues and problems into the curriculum and into the students' classroom experience, we can both transmit content knowledge and inspire a sense of civic responsibility and ownership for community problems. So, for example, if there is a problem in the campus, they should learn how to dialogue with authorities, stakeholders, colleagues in framing and defining the problem and the action to be taken. Such civic-engagement activities closely reflect the views of Dewey and Friere who extensively noted the objectives of education should be grounded in the interests of society and its renewal and development.

For example, in his article "Citizenship Courses as Life-Changing Experiences," William Coplin proposes an ice-breaker activity which he 
describes as "the awakening" (68). He suggests that the instructor can choose any relevant issue that has meaning to the students and at the same time related to the literary text that is being discussed (e.g. gender issues, discrimination, ...etc.) then the students are asked to take a position about that issue.

There is also the idea of keeping a minimum of requirement for volunteer work, which can be optional. Despite my awareness of the difficulty of asking students to participate in community service, this activity can be an ungraded requirement but for those who can do it, they can get extra credit. What encourages me to mention it here is that I found out that many students participate in voluntary work through various civil communities. For those who do not, they are encouraged to perform a service to someone in the campus community. This limited use of community experience, as Coplin mentions, has the purpose of awakening the students to the needs of their communities. But Benjamin R. Barber stressed that students should be aware that "serving others is not just a form of do-goodism or feel goodism, it is a road to social responsibility and citizenship" (xiii). Its success is dependent on proper preparation and adequate academic reflection in the form of essays and journals.

\section{Process:}

Before embarking on the mission of integrating civic engagement in their literature classes, instructors have to take strategic decisions concerning many issues like: the ILOs of the course, the scope of the civic engagement activity, and the grading strategy for the students' activities.

Firstly, most academic courses have among their ILOs developing communication skills, critical thinking and leadership skills. So, when the instructor designs the civic engagement activities, these goals should be integrated in both the academic work and the civic engagement activity. This means that academic activities should go hand in hand with the civic engagement activities. Carolyn Forestier has explained this point by stating that the academic activities usually involve critical thinking (through research paper), oral and written communication (in-class presentation, term papers, or letter writing), and leadership development (in-class or community projects) (467).

Secondly, every topic covered in the literature class has to have some civic engagement components. As for diffusing civic engagement activities as part of the course curriculum, the scope of the activity varies from one instructor to another. One instructor may use civic engagement activities as a supplement while another might prefer a larger scope which 


\section{Ghada Mahmoud Mamdouh Mohamed Abdel Hafeezr}

makes the content of the whole course revolves around the civic engagement activity. That depends on many factors like the experience of the instructor and the flexibility of the system that allows the instructor to make specific changes to the course.

Although it is beyond the scope of this paper to discuss the grading strategy for the civic-engagement activities, it is worth noting here that since it is difficult to evaluate students on the civic engagement activity, instructors should agree with the students from the beginning on the nature of the civic engagement activity that can be graded. Students can reflect on their civic-engagement activities using reaction paper, journal, blog, presentation, poster, etc. which can be graded according to certain rubrics.

After taking these strategic decisions, instructors, through mindful selection of the literary texts - texts that are reflective of the students' life experiences or through highlighting new focal points in the literature courses - in addition to the reconstruction of classroom interaction and incorporating and using a variety of appropriate civic-engagement activities, allow their students to become civically engaged.

When redesigning the course to incorporate civic engagement activities, it does not matter whether the texts selected are old or new and it does not matter neither if the course covers Elizabethan, Jacobian, Victorian, modern or contemporary writers. What matters however is that the instructor uses the text(s) to engage the students in timely and recent topics. So, for example Shakespeare's Othello (1603) can be analyzed from the perspectives of race, representation, the self vs other, difference, in addition to analyzing Desdemona as an early example of a feminist heroine who defies the patriarchal authority and marries outside her class and race. The theme of bonding too, which is manifested in the 'Willow Song' scene between Desdemona and Emilia and the bond between soldiers - Othello and Iago - that separates them from the civilians, can also be analyzed in the light of feminist and psychoanalytic approaches. Even Romeo and Juliet (1597), in addition to the elements of romantic tragedy that cannot be ignored, emphasis can be given to "the ancient grudge" between the two families and how it is turned into "mutiny" where "civil blood makes civil hands unclean" ("Prologue" 35). This is also a very timely angle that can be highlighted with reference either to local or global feuds and their tragic implications on the society. Emily Brontë's Wuthering Heights (1847) can also be read from a postcolonial perspective, analyzing the relation between home and abroad and center and margin and drawing similarities between Heathcliff and any other marginalized person/group in the society. In addition, the novel can be discussed from a feminist perspective which allows us to read Catherine 
as a powerful example of feminist revolt against the Victorian idealization of the angel in the house.

To make the proposed path more concrete, let's take "gender issues" as an example. The classroom as a liberating space for discussion can open multiple horizons for the students. While reading and analyzing women's misfortunes and limitations and gender-injustice issues in literary texts like Suzan Glaspell's Trifles (1916), David Mamet's Oleanna (1992), Ibsen's A Doll's House (1879), Kate Chopin's “A Story of an Hour" (1894), Jamaica Kincaid's "Girl" (1978), Maxine Hong Kingston's The Woman Warrior (1976) ... etc., students are encouraged to find links with the status of women nowadays with special emphasis on women's position in their local communities. To utilize the hallmarks of "civic instruction," students are asked to listen, interact, deliberate and to be responsive to certain gender issues which they can identity personally and socially.

To create civic-engagement atmosphere, students in groups can be asked to identify a contested issue of importance to them and then select a text - or an angle from a text - and try to "engage" through it in any creative way they see possible. All forms of intellectual potential are allowed and welcomed starting from acting, video screening, and ending with writing a letter to an editor about any form of harassment, for example. So, a group can create a wall magazine taking the literary text as the point of departure. Another might work with community members to create digital stories. With all the emphasis on analyzing the written words, it is equally important for students to appreciate the power of photographs. That's why a third group might collect some photographs related to the major issue they want to "engage" through and explain why they matter. A fourth one might think about interviewing several community members in an issue related to the main theme and then give a presentation. A fifth can invite a guest to shed light on any of the issues raised or have a debate. A sixth group - inspired by ecofeminism - may create green spaces in the campus. A final group may create a theatrical production based on the literary text/angle they engaged with in addition to their own experiences.

This proves Nadera Shalhoub-Kevorkian's belief that the classroom "not only serves as a formal center for the process of knowledge production, but also as a catalyst for social justice through the challenging of both injustice and unequal power arrangements (57). 


\section{Conclusion}

Having students work through social issues related to the literacy texts under study and trying to discover solutions not only through discussion but also through active participation reflect Dewey's and Friere's miniature community approach to teaching, which entails transforming the pedagogy of the classroom by extending its boundaries.

Literature classrooms can be a rich site to help students develop their civic capacities for civic engagement that might persist for the rest of their lives. As literature instructors, we can not only assist our students in developing a more complex understanding of the world but also nourish their realization that through their active engagement, they can help transform the world around them. This can be achieved through infusing civic-engagement atmosphere in the literature classroom, embracing instructional practices that explicitly emphasize the significance of civic engagement that center on multiple perspectives, active voice student-centeredness and empowerment, and finally connecting the course content to issues in the local or national communities. 


\section{Works Cited}

Barber, R. Benjamin. Foreword. Education for Citizenship: Ideas and Innovations in Political Learning, edited by Grant Reeher and Joseph Cammarano. Rowman \& Littlefield Publishers, INC., 1997, pp. ix-xiv.

Branson, Margaret Stimmann. "Education for Informed, Effective, and Committed Democratic Citizenship." Workshop Educating Youth for Active Citizenship, Dec. 11-13, 2014, Equatorial Hotel, Penang. Keynote Address. Google, http://www.civiced.org/resources/papers-and-speeches

Canfield, Kimberley P. "The Internet as a Tool for Student Citizenship." Education for Citizenship: Ideas and Innovations in Political Learning, edited by Grant Reeher and Joseph Cammarano. Rowman \& Littlefield Publishers, INC. 1997, pp. 215- 230.

Clark, J. Elizabeth. "The Digital Imperative: Making the Case for a 21st Century Pedagogy." Computers and Composition, vol. 27, no. 1, Mar. 2010, pp. 27-35. ScienceDirect, https://doi.org/10.1016/j.compcom.2009.12.004

Coleman, Joe. "Civic Pedagogies and Liberal-Democratic Curricula." Ethics, vol. 108, no. 4, July 1998, pp. 746-761. Jstor, https://www.jstor.org/stable/10.1086/233850

Coplin, William D. "Citizenship Courses as Life-Changing Experiences." Education for Citizenship: Ideas and Innovations in Political Learning, edited by Grant Reeher and Joseph Cammarano. Rowman \& Littlefield Publishers, INC, 1997, pp. 63-80.

Domagal-Goldman, Jennifer M. Teaching for Civic Capacity and Engagement: How Faculty Members Align Teaching and Purpose. PhD Thesis, The Pennsylvania State University, 2010. ProQuest,

http://mplbci.ekb.eg/MuseProxyID=1106/MuseSessionID=0611jp7p1/M useProtocol=https/MuseHost=search.proquest.com/MusePath/pqdtgloba 1/docview/816892194/5A31787EC758453BPQ/1?accountid=178282

Forestiere, Carolyn. "Promoting Civic Agency through Civic-Engagement Activities: A Guide for Instructors New to Civic-Engagement Pedagogy." Journal of Political Science Education, vol. 11, no. 4, Nov. 13, 2015, pp. 455-71. Taylor \& Francis Online, https://doi.org/10.1080/15512169.2015.1066684

Freire, Paola and Donaldo Macedo. Literacy: Reading the Word and the World. Greenwood Pub. Group, 1987.

Langer, Judith. Envisioning Literature: Literary Understanding and Literature Instruction. Teachers College P., 1995. 